\title{
Faktor Psikologis Yang Mempengaruhi Proses Terapi Anak Dengan Autisme
}

\author{
Elvina Rizky, Irfan Noor, dan Mahdia Fadhila \\ Universitas Islam Negeri Antasari Banjarmasin
}

\begin{abstract}
Autism is a developmental delay in children which is characterized by disorders in social aspects, communication. behavior and language. Treatment that will be given to children with autism which is therapy, like speech therapy, behavior, occupation and sensory integration. Based on preliminary studies and earlier research, found things that can affect both those that support and inhibit the implement of therapy. Therefore This study aims to decide what psychological factors affect the process therapy at the Center for Disability and Inclusion Education in South Kalimantan Province. This study uses a type of field research with a qualitative descriptive approach. The subjects in this study amounted to 6 therapists who have worked for 5 years at PLDPI. The results showed that therapeutic services at PLDPI, there are factors that influence the process and success of therapy. Internal factors that support the therapeutic process in PLDPI is the wishes of the child, age of child, level of autism disorders, IQ child, child's mood, affection therapist, therapist's patience and therapist's sincerity, ritual therapist (praying, prayer dhuha, reading istigfar and basmalah), intention of the therapist, understanding of children, enthusiasm and attendance consistency therapist, professional attitude. While external factors that support is selfawareness of people old in adopting a diet, parental support, the role of parents at home, therapist support, number adequate therapist, therapist collaboration with parents, adequate facilities and infrastructure and a therapeutic schedule that meets the target and therapy program that suits the child's needs. The internal factors that inhibit the child's condition such as hyperactivity, hypoactive, tantrum, sick, minimal eye contact, speech difficulties and disobedience and therapists who cannot controlling emotions. While the external factor is parents' want.
\end{abstract}

Keywords: psychological factors; autism therapy; autism.

\begin{abstract}
Abstrak
Autisme adalah keterlambatan perkembangan pada anak yang ditandai dengan gangguan pada aspek sosial, komunikasi, perilaku dan bahasa. Penanganan yang dapat diberikan pada anak dengan autisme yakni terapi, seperti terapi wicara, perilaku, okupasi dan sensori integrasi. Berdasarkan studi pendahuluan dan penelitian terdahulu, ditemukan hal-hal yang dapat mempengaruhi baik yang mendukung maupun menghambat dalam pelaksanaan terapi. Oleh sebab itu, penelitian ini bertujuan untuk mengetahui faktor psikologis apa saja yang mempengaruhi proses terapi di Pusat Layanan Disabilitas dan Pendidikan Inklusi Provinsi Kalimantan Selatan. Penelitian ini menggunakan jenis penelitian lapangan dengan pendekatan kualitatif. Subjek dalam penelitian ini berjumlah 6 orang terapis yang telah bekerja selama 5 tahun di PLDPI. Hasil penelitian menunjukkan bahwa pelayanan terapi di PLDPI, terdapat faktor-faktor yang mempengaruhi proses dan keberhasilan terapi. Faktor internal yang mendukung proses terapi di PLDPI yaitu keinginan anak, usia anak, tingkat gangguan autisme,
\end{abstract}


IQ anak, mood anak, kasih sayang terapis, kesabaran terapis dan keikhlasan terapis, ritual terapis (berdoa, shalat dhuha, membaca istigfar dan basmalah), niat terapis, pemahaman terhadap anak, semangat dan konsitensi kehadiran terapis, sikap profesional. Sedangkan faktor eksternal yang mendukung adalah kesadaran diri orang tua dalam menerapkan diet, dukungan orang tua, peran orang tua dirumah, dukungan terapis, jumlah terapis yang memadai, kerjasama terapis dengan orang tua, sarana dan prasarana yang memadai serta jadwal terapi yang memenuhi target dan program terapi yang sesuai dengan kebutuhan anak. Adapun faktor internal yang menghambat yakni kondisi anak seperti hiperaktif, hipoaktif, tantrum, sakit, kontak mata yang minim, kesulitan bicara dan ketidakpatuhan serta terapis yang tidak bisa mengendalikan emosi. Sedangkan faktor eksternalnya ialah keinginan orang tua.

Kata kunci: faktor psikologis; terapi autis; autisme.

Kehadiran anak sangatlah dinantikan oleh orang tua. Mereka mengharapkan anak yang lahir didunia dengan keadaan sempurna tanpa ada kekurangan baik fisik maupun psikis. Tetapi, tidak semua yang manusia inginkan dapat menjadi kenyataan. Sebagian orang tua diberikan anak seperti anak pada umumnya dan ada pula diberikan anak yang memiliki kebutuhan khusus.

Anak berkebutuhan khusus ialah anak luar biasa dengan karakteristik tertentu yang menjadikannya berbeda dengan anak pada umumnya tanpa selalu menunjukkan pada ketidakmampuan emosi, mental, atau fisik. Mereka yang memerlukan penanganan khusus yang berkaitan dengan kekhususannya, seperti autisme yang termasuk dalam kategori anak berkebutuhan khusus (Rachmayana, 2013).

Handojo mengungkapkan bahwa autisme bukanlah penyakit, melainkan sindrom yang ditandai dengan penyimpangan perkembangan sosial, kemampuan berbahasa dan rendahnya kepedulian terhadap lingkungan sekitarnya sehingga anak autis hidup dalam dunianya sendiri (Pieter dkk, 2011). Selain itu, Rachmayana juga mengatakan bahwa anak dengan autisme merupakan individu yang mengalami hambatan dalam proses interaksi sosial, komunikasi, perilaku, dan bahasa (Rachmayana, 2013). Direktur Rehabilitasi Anak Kementerian Sosial, Nahar menyebutkan jumlah penyandang autisme di Indonesia padaa 2015 diperkirakan mencapai 12.800 anak dengan autisme dan 134.000 penyandang spektrum autism (http://m.harnas.com). 
Gangguan yang dialami anak dengan autisme begitu luas, mencakup gangguan dalam komunikasi verbal dan nonverbal serta terganggu dalam interaksi sosial dan kontrol emosi, sehingga penderita autis bergantung pada penanganan yang diberikan (Fadli, 2010). Seorang psikolog, Rosdiana Setyaningrum menuturkan bahwa penanganan pada anak sebaiknya dilakukan sedini mungkin setelah orang tua mengetahui autisme pada anak, salah satunya yaitu terapi, sebagai perawatan standar untuk anak berkebutuhan khusus termasuk autisme (http://health.detik.com).

Seperti yang terdapat didalam hadis riwayat Muslim. Jabir bin Abdillah mengatakan bahwa Rasulullah SAW bersabda:

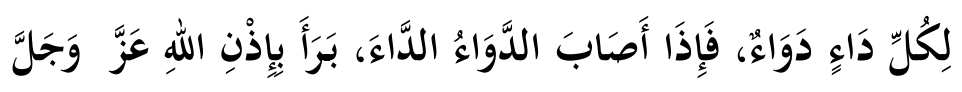

Artinya : "Setiap penyakit memiliki obat. Maka apabila sebuah obat sesuai dengan penyakitnya, dia akan sembuh dengan seizin Allah Subhanahu wa Ta'ala." (HR. Muslim)

Banyak pengobatan dengan terapi yang menghasilkan perubahan atau perbaikan pada gejala yang muncul pada anak dengan autisme, seperti terapi bicara, terapi okupasi dan terapi perilaku (Winarno, 2013). Terapi diberikan oleh terapis dengan tujuan untuk membangun kondisi yang lebih baik pada anak serta melatih anak agar mampu mengurangi masalah dan meningkatkan kemampuan komunikasi, beradaptasi dan bersosialisasi dengan lingkungan seperti anak pada umumnya (Prasetyoningsih, 2018).

Proses terapi di Pusat Layanan Disabilitas dan Pendidikan Inklusi Provinsi Kalimantan Selatan mempunyai beberapa tahapan, yaitu asesmen awal, asesmen program, penentuan layanan terapi, pelaksanaan terapi dan evaluasi. Pada studi pendahuluan, ditemukan hal-hal yang mempengaruhi proses pelaksanaan terapi baik pendukung maupun penghambat yang akan menentukan berhasil atau tidaknya proses terapi, seperti perilaku yang dimunculkan anak saat terapi, sikap profesional terapis dan kesabaran terapis.

Hasil penelitian Prianca Yulia Artanti mengenai gambaran pelaksanaan serta efektivitas terapi terhadap anak dengan autisme didapatkan hasil bahwa dalam pelaksanaan terapi terdapat beberapa hambatan, diantaranya yaitu kondisi anak yang hiperaktif, perilaku anak 
yang tidak terarah, kurangnya kefokusan anak, kesulitan anak dalam berbicara, kondisi anak saat tantrum, keadaan anak yang sakit, orang tua anak yang kurang kooperatif dalam menangani anak, sarana prasarana ditempat terapi yang kurang maksimal dan jadwal terapi yang laksanakan tidak memenuhi target yakni 40 jam/minggu, disebabkan biaya yang tidak selalu dapat dijangkau oleh pengguna jasa (Artanti, 2012).

Berdasarkan fakta yang sudah ditemukan dilapangan dan diperkuat dengan penelitian terdahulu membuat peneliti ingin mengetahui lebih dalam tentang faktor psikologis yang mempengaruhi proses terapi autisme dengan mengangkat judul penelitian "Faktor Psikologis yang Mempengaruhi Proses Terapi Anak dengan Autisme di Pusat Layanan Disabilitas dan Pendidikan Inklusi Provinsi Kalimantan Selatan".

\section{Metode}

Penelitian ini menggunakan jenis penelitian lapangan atau yang biasa disebut field research dengan pendeketan kualitatif, yakni data yang dikumpulkan berbentuk deskriptif berupa kata-kata dan gambar, bukan angka-angka. Apabila terdapat angka pada penelitian hanya bersifat sebagai data pendukung. Data yang diperoleh mencakup transkrip wawancara, catatan lapangan, foto, dokumen pribadi dan lain-lain. (Basrowi \& Suwandi, 2008). Selain itu penelitian ini ditujukan pada terapis untuk mengetahui lebih dalam tentang faktor psikologis yang mempengaruhi proses terapi anak dengan autisme.

\section{Subjek penelitian}

Subjek dalam penelitian ini sebanyak 6 orang terapis yang telah bekerja selama 5 tahun di Pusat Layanan Disabilitas dan Pendidikan Inklusi Provinsi Kalimantan Selatan.

\section{Teknik pengumpulan data}

Teknik pengumpulan data yang digunakan dalam penelitian ini yaitu wawancara semi terstruktur, yaitu bersifat fleksibel, setting natural, dan menekankan pada kedalaman bahasan agar didapatkan data yang lengkap dengan tujuan untuk menggali data sebanyak mungkin dari responden (Herdiansyah, 2010). Observasi dalam penelitian ini menggunakan observasi non partisipan, yaitu saat melakukan observasi, peneliti atau observer tidak ikut terlibat 
langsung dalam aktifitas yang dilakukan oleh subjek yang diteliti atau observee (Kusdianti dan fahmi, 2015). Dokumentasi yakni teknik pengumpulan data melalui sejumlah dokumen atau informasi yang didokumentasikan berupa dokumen tertulis maupun dokumen terekam, seperti catatan harian, memorial, kaset rekaman, foto dan sebagainya (Rahmadi, 2011). Adapun data yang peneliti ambil disini berupa file dan data-data berupa subfile yang didalamnya terdapat jumlah terapis dan jumlah anak dengan autisme dari tempat penelitian.

\section{Teknik Analisis Data.}

Teknik analisis data dilakukan setelah memperoleh semua data yang diperlukan dengan tujuan agar menemukan makna yang relevan mengenai faktor psikologis yang mempengaruhi proses terapi anak dengan autism. Tahapan analisis data yang digunakan yakni pengumpulan data, editing, koding dan menyimpulkan data (Sujarweni, 2014).

\section{Hasil}

Identitas Subjek dalam penelitian ini dapat dilihat pada tabel. 1 berikut ini:

Tabel 1

Identitas Subjek Penelitian

\begin{tabular}{|c|c|c|c|c|c|}
\hline No & Subjek & $\begin{array}{l}\text { Usia } \\
\text { (th) }\end{array}$ & $\begin{array}{c}\text { Pendidikan } \\
\text { Terakhir }\end{array}$ & Pekerjaan & $\begin{array}{c}\text { Lama } \\
\text { Bekerja } \\
\text { (th) }\end{array}$ \\
\hline 1 & RA & 25 & $\begin{array}{l}\text { S1 Pendidikan } \\
\text { Luar biasa }\end{array}$ & Terapis & 5 \\
\hline 2 & SR & 39 & $\begin{array}{l}\text { S1 Pendidikan } \\
\text { Luar biasa }\end{array}$ & Terapis & 6 \\
\hline 3 & NR & 39 & S1 Sosiologi & Terapis & 5 \\
\hline 4 & DA & 39 & S1 Psikologi & Terapis & 5 \\
\hline 5 & LP & 26 & $\begin{array}{l}\text { S1 Pendidikan } \\
\text { Luar biasa }\end{array}$ & Terapis & 6 \\
\hline 6 & NA & 31 & S1 Geografi & Terapis & 6 \\
\hline
\end{tabular}

Berdasarkan penelitian yang telah dilaksanakan di Pusat Layanan Disabilitas dan Pendidikan Inklusi Provinsi Kalimantan Selatan, diperoleh hasil yakni adanya faktor-faktor yang mempengaruhi proses terapi baik secara internal maupun eksternal yang berperan sebagai pendukung dan penghambat pelaksanaan terapi. Pada faktor internal yang 
mendukung proses terapi yaitu keinginan anak, seperti yang dikatakan para subjek bahwa keinginan anak dapat dilihat dari dari sikap dan perilaku anak yang tidak menolak dalam proses terapi. Sehingga mendukung kelancaran jalannya terapi karena anak mudah untuk diarahkan pada aktivitas. Keinginan anak juga berkaitan dengan home program, mood anak dan sikap terapis yang tidak memaksa untuk anak beraktivitas.

Perbedaan usia anak juga berpengaruh besar pada proses dan keberhasilan terapi yakni, usia anak yang muda saat diberikan terapi akan memudahkan pencapaian target atau sasaran dari program terapi itu sendiri. Pada anak yang usianya lebih tua cenderung merasa santai dan tidak ingin mengikuti instruksi dari terapis, sehingga untuk mencapai target tidak semudah anak yang berusia lebih muda. Hal ini akan menghambat proses terapi. Sedangkan pada hasil terapi juga terbukti bahwa anak yang berusia lebih muda mengalami banyak peningkatan daripada anak dengan usia yang lebih tua.

Selain itu, tingkatan gangguan autisme pada anak yaitu ringan, sedang dan berat dapat mempengaruhi proses terapi. Pada anak yang memiliki tingkat gangguan autisme ringan lebih mudah untuk melakukan aktivitas, adapun tingkatan gangguan sedang pada anak membuat terapis lebih banyak instruksi dibandingkan dengan gangguan autisme ringan. Sedangkan pada autisme berat memerlukan bantuan penuh dari terapis. Keberhasilan terapi pada anak yang tingkatan autisnya ringan lebih banyak mengalami kemajuan dari autisme sedang, adapun anak yang tingkat gangguan autismenya sedang lebih banyak mengalami perkembangan dibandingkan dengan anak yang tingkat gangguan autismenya lebih berat.

Pemberian terapi yang disertai dengan kasih sayang serta melakukan hal-hal yang menyenangkan bagi anak seperti kompak, bertepuk tangan dan bernyanyi akan membuat anak menjadi senang, sehingga hal ini juga berpengaruh pada kelancaran proses terapi. Selain kasih sayang, terapis juga perlu memiliki sikap sabar, seperti saat anak melakukan perilaku yang mengganggu proses terapi yang dapat menyakiti terapis maupun diri anak sendiri, dengan kesabaran akan membuat terapis tetap bisa fokus dan terapis menjadi lebih teliti untuk melihat perkembangan anak, sehingga memiliki pengaruh baik untuk kelancaran dan hasil proses terapi. Rasa ikhlas memberikan terapi yang dimiliki terapis dapat membuatnya merasa nyaman 
saat bekerja, selain itu juga berpengaruh pada suasana hati anak menjadi baik sehingga proses terapi dapat dijalankan.

Adapun faktor eksternal yang menjadi pendukung ialah dukungan orang tua seperti mengantar jemput anak ke tempat terapi, mengerjakan home program, konsultasi mengenai perkembangan anak dan menerapkan diet sangat mendukung kelancaran proses dan hasil terapi. Penerapan diet dengan menjaga makanan dan minuman yang konsisten pada anak juga berpengaruh besar pada berjalannya proses dan hasil terapi, seperti pada anak yang tidak diet atau masih sering kecolongan dietnya, anak akan memunculkan dampak dari apa yang dikonsumsinya. Apabila anak mengonsumsi mkanan yang tidak dianjurkan, maka akan membuat anak berperilaku tertawa-tawa atau menangis tanpa sebab. Hal ini membuat proses terapi tidak dapat dijalankan dengan maksimal. Selain itu, peran orang tua di rumah yang sama-sama tegas dalam menyikapi anak dengan autisme akan mendukung kelancaran proses terapi karena anak lebih patuh dan mudah diarahkan pada aktivitas. Akan tetapi, perbedaan dalam menyikapi anak seperti salah satu orang tua bersikap tegas dan satunya cenderung memanjakan anak akan dapat berpengaruh pada proses terapi seperti ketika terapis memberikan instruksi, anak tidak patuh, marah, anak sulit bertahan lama pada satu aktivitas dan menolak melakukan aktivitas lain. Hal ini tentunya berpengaruh pada proses pelaksanaan terapi.

Anak yang mengikuti terapi juga memerlukan dukungan dari terapis, karena berpengaruh dalam mendukung kelancaran terapi. di PLDPI, terapis memberikan dukungan berupa ketegasan yang membuat anak patuh, memeluk anak yang menangis dapat menenangkan anak, memberikan reward dan punishment, niat menerapi dengan sungguhsungguh, mampu mengendalikan suasan hati dan memilih program yang sesuai dengan kebutuhan anak. Jumlah terapis dalam pelayanan terapi dapat mendukung proses terapi, yakni dengan jumlah yang memadai dapat membuat terapis yang tidak ada jadwal menerapi untuk menggantikan terapis yang tidak dapat berhadir. Sehingga proses terapi anak dapat dijalankan sesuai dengan jadwal yang telah ditentukan. Kerjasama antara terapis dan orang tua memberikan pengaruh yang baik dan mendukung keberhasilan proses terapi. Bentuk kerjasama yang dijalin yakni konsultasi tentang perkembangan terapi anak dan pemberian 
home program yang akan membuat orang tua mengetahui perkembangan anak serta cara mengajarkan atau melatih kemampuan anak dirumah, sehingga anak juga berlatih ketika berada dirumah, tidak hanya di tempat terapi.

Tempat terapi juga dapat berpengaruh pada pelaksanaan terapi, seperti sarana dan prasarana yang memadai sangat membantu dalam proses terapi karena akan lebih mempermudah jalannya program terapi dan menghasilkan perkembangan yang baik pada anak dengan kelengkapan alat atau media terapi dan ruangan yang cukup memadai. Selain itu, jadwal terapi yang diberikan anak harus memenuhi target, PLDPI sendiri memiliki ketentuan jadwal pelaksanaan terapi anak, sehingga apabila anak mengikuti secara penuh jadwa yang sudah ditetapkan, maka akan mendukung keberhasilan terapi, sebab jika tidak memenuhi target seperti ketidakhadiran anak dapat memberikan dampak seperti penurunan perkembangan anak.

Pada proses terapi juga ditemukan faktor internal sebagai penghambat yakni kondisi atau keadaan hiperaktif pada anak seperti tidak bisa duduk tenang, tantrum seperti mengamuk dan menyakiti diri sendiri. Hal ini mengganggu jalannya terapi karena dapat membuang waktu terapi untuk menstabilkan kondisi anak yang hiperaktif dan tantrum. pada anak yang sakit bisa berdampak ada gerak tubuh anak yang cenderung lemah, menyebabkan pengurangan aktivitas terapi agar kondisi anak tidak semakin parah. Karakteristik yang ada pada anak dengan autisme seperti kontak mata yang minim, kesulitan berbicara, dan ketidakpatuhan membuat terapis lebih ekstra untuk mendapatkan pemahaman anak pada instruksi atau arahan terapis. Sedangkan faktor eksternal yang menghambat ialah keinginan kuat dari orang tua untuk anaknya dapat mengikuti terapi yang belum sesuai dengan kemampuan anak dapat menghambat jalannya proses dan keberhasilan terapi, karena tidak serasi dengan keinginan pada anak.

Berdasarkan wawancara yang dilakukan, diketahui pula ada beberapa faktor yang juga berpengaruh dalam proses terapi anak dengan autisme, yakni ritual terapis. Pada 5 orang subjek selain NA, melakukan ritual berdoa bersama anak yang sudah mampu secara verbal. Bagi anak yang non verbal, doa akan dibimbing oleh terapis saat memulai dan mengakhiri terapi. Sedangkan NA melakukan ritual doa dalam hati. Didalam doa, mereka berharap 
aktivitas terapi yang diberikan dapat berjalan dengan lancar dan menghasilkan perkembangan yang baik pada anak. Setelah berdoa, mereka merasa lebih tenang, lebih fokus dan siap untuk menerapi. Selain itu, doa bersama anak bisa mendekatkan terapis, adanya chemistry dengan anak dan dapat melatih program yang terapis berikan seperti kontak mata yang dilakukan anak saat diinstruksikan sikap berdoa dengan tangan menengadah. Hal ini tentunya akan mempermudah dan memperlancar proses terapi yang dijalankan.

Selain ritual berdoa, SR juga mengamalkan bacaan istigfar sebanyak 3 kali sebelum dan sesudah terapi. Pada NR juga membaca istifgar ketika menghadapi anak yang menangis atau tantrum. Setelah membaca istigfar, subjek merasa semakin tenang dan damai yang kemudian akan menghasilkan rasa tenang pula pada diri anak.

Memulai pelaksanaan terapi dengan membaca basmalah, selain membiasakan anak membaca basmalah ketika mengawali sesuatu, subjek LP juga meyakini proses terapi dapat berjalan dengan lancar.

Menjalankan ritual seperti shalat dhuha bagi DA dilakukan karena menurutnya dalam menerapi perlu sepenuh hati disertai rasa ikhlas agar terapi yang diberikan tidak asal-asalan. Dengan melaksanakan shalat dhuha selain untuk mendekatkan diri dengan sang pencipta, juga dapat menstabilkan emosi. DA pun dapat memilah emosi yang tepat saat menerapi, fokus pada pekerjaan dan mengesampingkan permasalahan pribadi agar tidak mengganggu aktivitas terapi dan dapat memperlancar proses terapi.

Bekerja sebagai terapis yang dimulai dengan niat yang sungguh-sungguh membuat para subjek akan melaksanakan pekerjaannya dengan kesungguhan pula, lebih tulus memberikan terapi dan tidak menjadikan pekerjaan sebagai beban, karena apabila terapi tidak disertai dengan niat akan membuat terapis malas, sehingga terapi yang diberikan tidak maksimal. Selain itu, niat bekerja untuk ibadah dan menolong anak memiliki pengaruh pada terapis, yakni lebih bisa mengontrol emosi dan menyingkirkan perasaan lelah atau masalah pribadi, sehingga pelayanan dapat berjalan dengan baik. Anak pun lebih menikmati proses pelaksanaan terapi dan mematuhi instruksi terapis serta tidak uring-uringan yang akan menghasilkan peningkatan pada perkembangan anak. 
Seluruh subjek mengatakan bahwa dalam pelaksanaan terapi, terapis memang harus lebih memahami anak, seperti sifat dan karakter anak, kebiasaan anak ketika ingin buang air kecil dan hal yang disukai anak. Seperti yang lakukan saat anak merasa bosan, yakni dengan mengajak anak bernyanyi dan berhitung untuk menyelingi aktivitas terapi. Hal ini membuat anak mau beraktivitas kembali, sehingga memudahkan terapis dalam menangani anak dan memperlancar jalannya terapi.

Pelayanan terapi yang diberikan subjek RA, SR dan LP pernah terbawa masalah pribadi yang dapat berpengaruh pada proses terapi seperti selain ekspresi wajah terapis yang cemberut, ada pula anak yang dibiarkan beraktifitas sendiri karena subjek menghindari emosi yang dirasakannya agar tidak berimbas pada anak. Terapi yang diberikan menjadi kurang maksimal sebab fokus subjek terbagi dengan memikirkan hal lain. Anak yang diterapi juga bisa membaca keadaan terapis, sehingga dapat membuat suasana hati anak berubah. Sedangkan pada DA dan NA yang tidak pernah membawa permasalahan pribadi saat menerapi berpendapat hal tersebut bisa menjadikan ketidaksungguhan dalam menerapi dan anak tidak terlayani dengan sepenuh hati. Apabila terapis bisa mengesampingkan masalah tersebut, maka terapi akan berjalan dengan tenang.

Dalam menerapi anak, semangat terapis juga diperlukan karena akan membuat anak yang diterapi menjadi bersemangat pula untuk melakukan aktivitas serta konsistensi masuk kerja akan membuat anak bingung jika diterapi dengan terapis lain karena perbedaan penyampaian terapi pada anak.

Perbedaan intelligence quotion pada anak memiliki pengaruh pada kelancaran proses terapi, yakni pemahahaman anak pada instruksi terapis lebih cepat ditangkap oleh anak yang mempunyai IQ tinggi dibandingkan anak dengan IQ rendah.

Mood anak yang baik ketika sampai di tempat terapi membuatnya ingin mengerjakan aktivitas yang diberikan terapis, sehingga terapi dapat dijalankan. Sedangkan mood anak yang sudah rewel dari rumah menjadikan anak marah saat diberi instruksi dapat membuat terapi tidak bisa berjalan dengan lancar.

Pemberian terapi pada anak dengan autisme memerlukan program yang sesuai dengan kebutuhan anak karena akan memudahkan dalam proses pelaksanaan dan keberhasilan terpi. 
Apabila tidak sesuai seperti program anak yang terlalu tinggi, maka berdampak pada lambatnya perkembangan dari target yang telah ditetapkan.

Bagi RA dalam menerapi anak lebih sering muncul emosi sepeerti saat anak tidak mau mengikuti arahan terapis. Jika tidak bisa mengendalikan emosinya, dapat membuat anak menangis atau tantrum. Selain itu anak juga bisa trauma dengan aktivitas yang diberikan, seperti lempar tangkap bola basket, tanpa disadari terapis melempar bola hingga terkena wajah anak. Hal ini bisa menimbulkan trauma dengan bola basket dan diganti memakai bola yang lain seperti bola kain. Maka proses terapi tidak dapat diberikan secara maksimal.

Selain ciri hiperaktif, terdapat hipoaktif pada anak dengan autisme yang juga dapat menghambat dalam pemberian terapi karena gerak tubuh yang lambat membuat anak memerlukan waktu yang lama dalam menyelesaikan aktivitas terapi.

\section{Pembahasan}

Keinginan anak untuk mengikuti terapi yang terlihat dari sikap dan perilaku anak yang tidak menolak ketika proses terapi. Sehingga anak mudah untuk di arahkan pada aktivitas. Serupa dengan hasil penelitian Izza Turruqayah mengenai pelaksanaan terapi musik pada anak dengan autisme yaitu keinginan yang dimiliki anak untuk diterapi menjadi salah satu faktor pendukung jalannya terapi karena anak akan mengikuti aktivitas yang diberikan (Turruqoyah, 2017).

Semakin muda usia anak dalam melakukan terapi, semakin besar kemungkinan untuk berhasil. Usia ideal anak antara 2-5 tahun, di mana sel otak masih bisa dirangsang untuk membentuk cabang neuron baru (Maulana, 2014). Seperti yang terdapat di PLDPI, perbedaan usia anak juga berpengaruh besar pada proses dan keberhasilan terapi yakni, usia anak yang muda saat diberikan terapi akan memudahkan pencapaian target atau sasaran dari program terapi itu sendiri. Pada anak yang usianya lebih tua cenderung merasa santai dan tidak ingin mengikuti instruksi dari terapis, sehingga untuk mencapai target tidak semudah anak yang berusia lebih muda. Hal ini akan menghambat proses terapi. Sedangkan pada hasil terapi juga terbukti bahwa anak yang berusia lebih muda mengalami banyak peningkatan daripada anak dengan usia yang lebih tua. 
Terdapat 3 tingkatan gangguan autisme pada anak di PLDPI yaitu ringan, sedang dan berat dapat mempengaruhi proses terapi. Pada anak yang memiliki tingkat gangguan autisme ringan lebih mudah untuk melakukan aktivitas, adapun tingkatan gangguan sedang pada anak membuat terapis lebih banyak instruksi dibandingkan dengan gangguan autisme ringan. Sedangkan pada autisme berat memerlukan bantuan penuh dari terapis. Keberhasilan terapi pada anak yang tingkatan autisnya ringan lebih banyak mengalami kemajuan dari autisme sedang. Adapun anak yang tingkat gangguan autismenya sedang lebih banyak mengalami perkembangan dibandingkan dengan anak yang tingkat gangguan autismenya lebih berat. Pengaruh dari tingkatan gangguan autisme pada anak dalam pelayanan terapi di PLDPI serupa dengan hasil penelitian Mega Nurul Anah tentang pengaruh terapi murottal terhadap aktifitas motorik anak dengan autisme, yaitu terdapat hambatan yang mempengaruhi terapi, salah satunya ialah tingkatan gangguan autisme pada anak (Anah, 2016).

Pemberian terapi yang disertai dengan kasih sayang serta melakukan hal-hal yang menyenangkan bagi anak seperti kompak, bertepuk tangan dan bernyanyi akan membuat anak menjadi senang, sehingga hal ini juga berpengaruh pada kelancaran proses terapi. serupa dengan pengertian Muhammad Anis tentang sayang yang dikutip oleh Rahmatullah, yaitu sebagai perbuatan dari seseorang yang memberikan kenyamanan, kesenangan, keharmonisan dan rasa penghargaan kepada orang lain (Rahmatullah, 2014). Para subjek mengungkapkan bahwa mereka mengasihi anak seperti anak sendiri dan mengutamakan kasih sayang pada anak karena selain kekurangan yang anak miliki, anak juga dapat merasakan kasih sayang dari terapis. Kasih sayang terapis memiliki pengaruh pada proses terapi seperti anak merasa nyaman dan mau mengerjakan aktivitas terapi dengan tenang. Sehingga terapis juga lebih mudah menangani anak karena respon anak yang baik dan menghasilkan aktivitas terapi yang baik juga pada anak. Pengaruh tersebut sejalan dengan pernyataan Muhammad Anis yang dikutip oleh Rahmatullah, yakni sebenarnya Allah telah mengajarkan kepada umat manusia untuk senantiasa memiliki sifat rahmah yang dimaksud sifat penuh kasih sayang terhadap makhluk-makhluk sesama manusia maupun selain manusia, sebab yang menyayangi akan selalu memberikan kebaikan kepada yang disayangi (Rahmatullah, 2014). 
Selain kasih sayang, terapis juga perlu memiliki sikap sabar, seperti menghadapi anak yang berperilaku mengganggu proses terapi, menyakiti terapis seperti memukul, mencubit, menendang, meludahi terapis maupun diri anak sendiri, dengan kesabaran akan membuat terapis tetap bisa fokus dan terapis menjadi lebih teliti untuk melihat perkembangan anak, sehingga memiliki pengaruh baik untuk kelancaran dan hasil proses terapi. hal ini sejalan dengan teori yang diungkapkan oleh Ubaedy, yakni orang yang sabar adalah orang yang tetap memfokuskkan pikiran, hati dan tindakannyaa untuk meraih apa yang diinginkan dengan tetap melawan godaan batin dan mengatasi tantangan kesulitan yang muncul di tengah jalan (Ubaedy, 2009).

Rasa ikhlas memberikan terapi yang dimiliki terapis dapat membuatnya tidak merasa berat merasa nyaman saat bekerja, selain itu juga berpengaruh baik pula pada suasana hati anak menjadi baik sehingga proses terapi dapat dijalankan. Sependapat dengan penelitian terdahulu oleh Martiyani, juga ditemukan hasil bahwa mendidik anak dengan autisme perlu disertai dengan penuh kesabaran dan keikhlasan merupakan salah satu kunci yang harus dimiliki oleh terapis, tanpa didasari dengan itu pelaksanaan proses terapi tidak akan berhasil dengan maksimal, karena pada dasarnya anak autis merupakan anak yang istimewa yang bisa merasakan serta memiliki rasa sensitif yang tinggi terhadap lingkungan sekitar (Martiyani, 2017).

Penerapan diet dari orang tua dalam menjaga makanan dan minuman yang konsisten pada anak di PLDPI juga berpengaruh besar pada berjalannya proses dan hasil terapi, seperti pada anak yang tidak diet atau masih sering kecolongan dietnya, anak akan memunculkan dampak dari apa yang dikonsumsinya. Apabila anak mengonsumsi mkanan yang tidak dianjurkan, maka akan membuat anak berperilaku tertawa-tawa atau menangis tanpa sebab. Hal ini membuat proses terapi tidak dapat dijalankan dengan maksimal. Pengaruh tidak diet pada anak serupa dengan hasil penelitian Rifmie dan Fillah mengenai hubungan skor frekuensi diet bebas gluten dan bebas casein dengan skor perilaku, yakni anak yang memiliki frekuensi rendah dalam mengonsumsi makanan baik casein maupun gluten, terjadi perubahan perilaku yang lebih terarah dibandingkan anak yang memiliki kebiasaan frekuensi yang tinggi dalam 
mengonsumsi gluten dan casein, seperti anak menjadi lebih tenang, tidak mudah menangis atau marah dan mudah diberikan instruksi saat terapi (Pratiwi dan Dieny, 2014).

Dukungan sosial pada umumnya menggambarkan mengenai peranan atau pengaruh yang dapat ditimbulkan oleh orang lain yang berarti seperti anggota keluarga, teman, saudara, dan guru. Orang tua merupakan suatu bentuk dukungan sosial yang mampu menentukan kesehatan dan perkembangan pada anak berkebutuhan khusus, baik secara fisik maupun psikologis. Seperti yang terdapat di PLDPI, dukungan orang tua pada anak antara lain mengantar jemput anak ke tempat terapi, mengerjakan home program, konsultasi mengenai perkembangan anak dan menerapkan diet. Dukungan tersebut tentunya akan menghasilkan kemajuan pada perkembangan aktivitas anak, sehingga target hasil program anak tercapai lebih cepat. Selain itu, pada anak yang mendapatkan dukungan penuh akan mempermudah proses terapi seperti respon anak yang cepat terhadap instruksi terapis karena anak sudah terlatih dari aktivitas home program yang diterapkan orang tua di rumah. Pengaruh dukungan orang tua bagi kelancaran proses terapi juga ditemukan pada hasil penelitian dari Izza Turruqayah bahwa dukungan orang tua menjadi salah satu faktor pendukung dari pelaksanaan terapi musik, salah satunya dengan mengerjakan saran dari para terapis yang didapatkan setelah berkonsultasi mengenai anak (Turruqoyah, 2017).

Selain itu, peran orang tua di rumah yang sama-sama tegas dalam menyikapi anak dengan autisme akan mendukung kelancaran proses terapi karena anak lebih patuh dan mudah diarahkan pada aktivitas. Sedangkan perbedaan dalam menyikapi anak seperti salah satu orang tua bersikap tegas dan satunya cenderung memanjakan anak akan dapat berpengaruh pada proses terapi seperti ketika terapis memberikan instruksi, anak tidak patuh, marah, anak sulit bertahan lama pada satu aktivitas dan menolak melakukan aktivitas lain. Hal ini sejalan dengan penelitian-penelitian yang telah dilakukan mindspace learning and research, hampir semua menyatakan bahwa sikap, pengasuhan dan kondisi orang tua secara langsung atau tidak langsung akan mempengaruhi kemampuan pengendalian emosi anak (Zahara, 2017).

Handojo mengatakan bahwa untuk mendukung kelancaran proses terapi perlu dilakukan inventarisasi berbagai item yang berefek imbalan pada anak mulai dari materi seperti makanan, minuman dan barang-barang tertentu, secara verbal seperti pujian, nyanyian, 
berupa taktil seperti pelukan, ciuman, belaian, kelitikan dan tepukan atau dengan aksi tertentu seperti toss dan yes (Sulistyawati, 2018). Subjek juga memberikan dukungan pada anak, yakni berupa ketegasan yang membuat anak patuh, memeluk anak yang menangis dapat menenangkan anak, memberikan reward dan punishment, niat menerapi dengan sungguhsungguh, mampu mengendalikan suasan hati dan memilih program yang sesuai dengan kebutuhan anak. Pengaruh positif dari bentuk dukungan terapis sebagai pendukung bagi kelancaran dan hasil terapi anak sesuai dengan penelitian Martiani yang mendapatkan salah satu faktor pendukung jalannya pelaksanaan terapi, yaitu dukungan guru kelas atau terapis (Martiyani, 2017).

Jumlah tenaga terapis dalam pelayanan terapi di PLDPI cukup memadai, sehingga apabila terdapat terapis yang tidak bisa berhadir, terapis yang tidak ada jadwal menerapi akan menggantikannya, tentunya hal ini membuat proses terapi anak dapat dijalankan sesuai dengan jadwal yang telah ditentukan. Penelitian yang dilakukan Heriyono di YCBK, ditemukan kendala saat memberikan pelayanan terapi, yakni kurangnya tenaga pengasuh atau terapis menjadikan peran ganda dalam menangani anak hingga mengakibatkan kurangnya efektifitas pengasuh dalam memberikan pelayanan (Heriyono, 2017).

Kerjasama antara terapis dan orang tua memberikan pengaruh yang baik serta mendukung keberhasilan proses terapi. Bentuk kerjasama yang dijalin yakni konsultasi tentang perkembangan terapi anak dan pemberian home program yang akan membuat orang tua mengetahui perkembangan anak serta cara mengajarkan atau melatih kemampuan anak dirumah, sehingga anak juga berlatih ketika berada dirumah, tidak hanya di tempat terapi. Hal ini sejalan dengan yang teori yang dikemukakan Hasdianah bahwa keberhasilan program terapi sangat ditentukan oleh bagus tidaknya kerjasama orang tua dengan orang-orang yang terlibat dalam pengasuhan sehari-hari, kerjasama ini berkaitan dengan proses transfer keterampilan yang telah diperoleh selama terapi, kemudian harus dipelihara dan ditingkatkan dalam kehidupan di luar program terapi (Hasdianah, 2013).

Tempat terapi juga dapat berpengaruh pada pelaksanaan terapi, seperti sarana dan prasarana yang memadai sangat membantu dalam proses terapi karena akan lebih mempermudah jalannya program terapi dan menghasilkan perkembangan yang baik pada 
anak dengan kelengkapan alat atau media terapi dan ruangan yang cukup memadai. Sejalan dengan penelitian Martiyani, sarana dan prasarana yang lengkap untuk terapi snoezelen seperti ruang khusus disertai dengan media lampu warna-warni dan musik klasik bagi anak yang hipoaktif dan musik orkes bagi anak hiperaktif menjadi pendukung keberhasilan terapi (Martiyani, 2017).

Selain itu, jadwal terapi yang diberikan anak harus memenuhi target, di PLDPI memiliki ketentuan jadwal pelaksanaan terapi anak yakni 6-8 pertemuan setiap minggunya dengan durasi 45 menit untuk satu kali pertemuan, sehingga apabila anak mengikuti secara penuh jadwal yang sudah ditetapkan, maka akan mendukung keberhasilan terapi, sebab jika tidak memenuhi target seperti ketidakhadiran anak dapat memberikan dampak seperti penurunan perkembangan anak. Hal ini juga serupa dengan temuan faktor yang menghambat terapi dalam penelitian Prianca, yakni terapi anak yang tidak penuh dijalankan seperti jadwal terapi yang telah ditentukan karena biaya pelaksanaan terapi tidak selalu dapat dijangkau oleh pengguna jasa (Artanti, 2012).

Kondisi atau keadaan hiperaktif pada anak seperti tidak bisa duduk tenang, tantrum seperti mengamuk dan menyakiti diri sendiri. Hal ini mengganggu jalannya terapi karena dapat membuang waktu terapi untuk menstabilkan kondisi anak yang hiperaktif dan tantrum. pada anak yang sakit bisa berdampak ada gerak tubuh anak yang cenderung lemah, menyebabkan pengurangan aktivitas terapi agar kondisi anak tidak semakin parah. Karakteristik yang ada pada anak dengan autisme seperti kontak mata yang minim, kesulitan berbicara, dan ketidakpatuhan membuat terapis lebih ekstra untuk mendapatkan pemahaman anak pada instruksi atau arahan terapis. Pengaruh enam kondisi anak yang bisa menghambat pelaksanaan terapi serupa dengan hasil penelitian Prianca Yulia Artanti mengenai gambaran terapi terhadap anak dengan autisme di Mutia Center Kecamatan Bojong Kabupaten Purbalingga, yakni perilaku hiperaktif, kesulitan bicara, kondisi anak ketika tantrum, sakit, minimnya kontak mata dan kepatuhan anak yang masih belum dapat diarahkah (Artanti, 2012).

Keinginan kuat dari orang tua untuk anaknya dapat mengikuti terapi yang belum sesuai dengan kemampuan anak dapat menghambat jalannya proses dan keberhasilan terapi. Sama halnya dengan hasil penelitian yang ditemukan oleh Izza Turruqayah, orang tua yang 
menginginkan anaknya untuk menyukai atau dapat bermain musik seperti dirinya, sehingga mendesak anak untuk mengikuti terapi musik menjadi penghambat keberhasilan terapi (Turruqoyah, 2017).

Yusuf Qardhawi menyebutkan bahwa pada hakikatnya doa merupakan upaya yang dilakukan untuk mendekatkan diri kepada Allah SWT, melalui cara yang benar dan sesuai dengan petunjuk Rasulullah SAW, maka akan membuahkan hasil seperti orang yang berdoa akan merasakan akhlaknya semakin bernilai serta akan tercapai perasaan tenang, sebagaimana yang dirasakan oleh Rasulullah SAW, ketika pulang dari Tha'if dalam keadaan terluka sebab dari perlakuan penduduk Thai'if. Dengan berdoa hati beliau menjadi sejuk dan damai (Kuswandi, 2018). Serupa dengan doa yang diterapkan para subjek dengan harapan aktivitas terapi yang diberikan dapat berjalan lancar dan menghasilkan perkembangan yang baik pada anak, didapatkan rasa tenang, fokus dan terciptanya chemistry setelah berdoa yang dapat mempermudah dan memperlancar proses terapi yang dijalankan.

Subjek SR mengamalkan bacaan istigfar sebanyak 3 kali sebelum dan sesudah terapi. Pada NR juga membaca istifgar ketika menghadapi anak yang menangis atau tantrum. Setelah membaca istigfar, subjek merasa semakin tenang dan damai yang kemudian akan menghasilkan rasa tenang pula pada diri anak. Serupa dengan yang dikatakan Abu Utsman Kharisman bahwa istigfar semacam doping atau obat peningkat performa yang melipat gandakan tenaga dan kekuatan individu baik lahir maupun batin (Kharisman, t.t)

Terdapat hadits tentang bacaan basmalah yang dikutip oleh Athuoullah Ahmad dalam tulisan An-Nazili yang diambil berdasarkan al-Durr Mantsur, yaitu telah diriwayatkan dari Ibn Abbas, dia menyatakan bahwa Rasulullah bersabda: "Barang siapa membaca bismillahirrahmanirrahim la haula wala quwwata illa billahil aliyil adzim, maka Allah akan menghilangkan tujuh puluh pintu bahaya, keraguan, kesusahan dan kebosanan." (Ahmad, 2007). Subjek LP memulai pelaksanaan terapi dengan membaca basmalah, selain membiasakan anak membaca basmalah ketika mengawali sesuatu, subjek LP juga meyakini proses terapi dapat berjalan dengan lancar.

Sholat dhuha dimulai sejak pukul 07.00 hingga sebelum masuk waktu sholat dzuhur yang mana pada saat itu manusia mulai sibuk menggunakan otaknya dalam memulai aktifitas 
bekerja, sehingga segala pekerjaan yang diawali dengan melaksanakan sholat dhuha akan membuat seseorang lebih mengingat Allah SWT, yang kemudian menghasilkan ketenangan jiwa dan pikiran, pemulihan sel-sel otak serta motivasi diri, sholat dhuha dapat memberikan keuntungan pada otak karena dapat meningkatkan fungsi kerja otak sebelum bekerja, sehingga akan menghasilkan pekerjaan yang maksimal (Waid, 2012). Sama halnya seperti pada diri DA yang menjalankan sholat dhuha setiap pagi, menurutnya dalam menerapi perlu sepenuh hati disertai rasa ikhlas agar terapi yang diberikan tidak asal-asalan. Dengan melaksanakan shalat dhuha selain untuk mendekatkan diri dengan sang pencipta, juga dapat menstabilkan emosi, fokus pada pekerjaan dan mengesampingkan permasalahan pribadi agar tidak mengganggu aktivitas terapi.

Pengaruh niat sungguh-sungguh seperti untuk ibadah dan menolong anak dalam bekerja dapat mendukung kelancaran proses terapi, sebab para subjek melaksanakan pekerjaan dengan kesungguhan, rasa tulus, lebih bisa mengontrol emosi dan menyingkirkan perasaan lelah, tidak menjadikan pekerjaan sebagai beban. Anak yang diterapi juga lebih menikmati proses pelaksanaan terapi dan mematuhi instruksi terapis serta tidak uring-uringan, sehingga menghasilkan peningkatan pada perkembangan anak. Apabila terapi tidak disertai dengan niat akan membuat terapis malas, maka terapi yang diberikan tidak maksimal. Sebagaimana Nawawi mengemukakan tentang niat yang dikutip oleh Siti Hidayah dan Haryani, yakni dasar yang sangat penting bagi setiap perilaku, bahkan menjadi alat ukur untuk setiap perilaku, nilai suatu perilaku sangat bergantung pada niat. Jika berniat baik, maka perilaku tersebut menjadi baik. Sebaliknya, apabila niat buruk maka perilaku tersebut juga buruk (Hidayah dan Haryani, 2013).

Pemahaman terapis terhadap sifat dan karakter anak, kebiasaan anak ketika ingin buang air kecil dan hal yang disukai anak. Seperti mengajak anak bernyanyi dan berhitung terapi ketika anak merasa bosan, ini akan membuat anak ingin beraktivitas kembali, sehingga memudahkan terapis dalam menangani anak dan memperlancar jalannya terapi. Faktor terapis dalam memahami anak termasuk upaya yang dilakukan untuk mendukung proses terapi, seperti teori yang dikemukakan Johnson dan Johnson mengenai dukungan sosial yaitu sebagai 
keberadaan orang lain yang berperan membantu, semangat, penerimaan dan perhatian, sehingga bisa meningkatkan kesejahteraan individu (Turruqoyah, 2017).

Terbawanya permasalahan pribadi dalam proses terapi menyebabkan perubahan ekspresi wajah subjek seperti cemberut, ada pula yang didiamkan untuk beraktifitas sendiri karena subjek menghindari emosi yang dirasakannya agar tidak berimbas pada anak. hal ini tentunya, menjadikan terapi kurang maksimal sebab fokus subjek terbagi dengan memikirkan hal lain. Anak yang diterapi juga bisa membaca keadaan terapis, sehingga dapat membuat suasana hati anak berubah. Hal ini berhubungan pula dengan salah satu dari lima bagian kecerdasan emosional teori Goleman yang dapat mempengaruhi keberhasilan seseorang dalam bekerja yaitu self management atau pengaturan diri yang merupakan suatu kemampuan seseorang dalam mengendalikan dan menangani emosinya sendiri sedemikian rupa sehingga berdampak positif pada pelaksanaan tugas, peka terhadap kata hati serta sanggup menunda kenikmatan sebelum tergapainya target yang diinginkan serta mampu kembali pada emosi yang stabil (Rahmasari, 2012).

Melaksanakan terapi perlu diiringi dengan semangat terapis karena akan menjadikan anak bersemangat pula dalam beraktivitas serta konsistensi kehadiran terapis yang membuat anak bingung apabila terapi harus digantikan dengan terapis karena perbedaan penyampaian terapi pada anak. Hal ini sesuai dengan adanya motivasi pada terapis akan menjadi penopang bagi motivasi belajar anak yang terbilang rendah atau tidak ada sama sekali (Jannah dkk, 2018).

Penelitian yang dilakukan oleh Ahmad Ma'ruf dan Lailatul Magfirah ditemukan hasil bahwa salah satu anak yang memiliki IQ lebih tinggi, anak akan patuh pada terapis, lebih mudah menangkap instruksi dan menirukan gerakan terapi, sehingga dapat mendukung jalannya proses dan keberhasilan terapi (Ma'ruf dan Maghfiroh, 2017). Hal ini serupa dengan IQ (Intelligence quotion) pada pernyataan subjek, yakni anak yang mempunyai IQ tinggi akan lebih cepat memahami instruksi terapis lebih dibandingkan anak dengan IQ rendah.

Selain itu, mood anak yang baik ketika akan diterapi membuatnya ingin mengerjakan aktivitas yang diberikan terapis, sehingga terapi pun dapat dijalankan. Sedangkan mood anak yang tidak baik seperti rewel dari rumah, dapat membuat anak marah saat diberi instruksi sehingga terapi tidak bisa berjalan dengan lancar. 
Mirza Maulana mengatakan, setiap anak yang akan diterapi sebaiknya mendapatkan evaluasi yang lengkap dari dokter dan para terapis, kemudian dibuatkan kurikulum individual berdasarkan kemampuan anak dalam setiap bidangnya (Maulana, 2014). Sama halnya dengan yang dilakukan subjek yakni memberikan program terapi sesuai dengan kebutuhan anak. Hal ini dilakukan agar program yang anak jalankan tepat dengan apa yang diperlukan. Apabila tidak sesuai seperti program anak yang terlalu tinggi, maka berdampak pada lambatnya perkembangan dari target yang telah ditetapkan.

Bagi subjek RA, ketika anak tidak mau mengikuti arahan terapis sering kali memunculkan emosi. Jika tidak bisa mengendalikan emosi yang sedang dirasakan, dapat membuat anak menangis atau tantrum. Selain itu anak juga bisa trauma dengan aktivitas yang diberikan, seperti lempar tangkap bola basket, tanpa disadari terapis melempar bola hingga terkena wajah anak. Hal ini bisa menimbulkan trauma dengan bola basket dan diganti memakai bola yang lain seperti bola kain. Maka proses terapi tidak dapat diberikan secara maksimal. Trauma yang didapatkan anak dari kejadian tersebut sesuai definisi trauma dari American Psychiatric Association yaitu trauma terjadi karena peristiwa pahit baik fisik atau mental yang menyebabkan kerusakan langsung pada tubuh atau kejutan pada pikiran (Hatta, 2015).

Hipoaktif pada anak memang sebagai salah satu karakteristik anak dengan autisme. Kondisi hipoaktif dapat menghambat anak dalam mengerjakan aktivitas terapi karena gerak tubuh yang lambat membuat anak memerlukan waktu yang lama untuk menyelesaikannya. Serupa dengan penelitian Yanuar Dian, hipoaktif yang ditandai dengan gerakan tubuh anak yang lambat juga menjadi penyebab kesulitan anak untuk menggerakan motorik kasar dalam pemberian senam irama seperti melangkah, melompat mengayunkan tangan dan berjalan dikarenakan anak memiliki badan yang lemas dan tidak ada kekuatan untuk bergerak (Pradana, t.t). 


\section{Kesimpulan}

Berdasarkan uraian diatas, dapat disimpulkan bahwa dalam pelayanan terapi di Pusat Layanan Disabilitas dan Pendidikan Inklusi Provinsi Kalimantan Selatan bagi anak dengan autisme, telah ditemukan faktor-faktor yang dapat mempengaruhi proses terapi baik pendukung maupun penghambat yang dibagi menjadi dua yakni faktor internal dan eksternal. Faktor internal yang mendukung yakni keinginan anak, usia anak, tingkat gangguan autisme, IQ anak, mood anak, kasih sayang terapis, kesabaran terapis dan keikhlasan terapis, ritual terapis (berdoa, shalat dhuha, membaca istigfar dan basmalah), niat terapis, pemahaman terhadap anak, semangat dan konsitensi kehadiran terapis serta sifat profesional. Faktor eksternal yang mendukung yaitu konsistensi orang tua dalam menerapkan diet, dukungan orang tua, peran orang tua dirumah, dukungan terapis, jumlah terapis yang memadai, kerjasama terapis dengan orang tua, sarana dan prasarana yang memadai jadwal terapi yang memenuhi target dan program terapi yang sesuai dengan kebutuhan anak. Faktor internal yang menghambat ialah kondisi anak seperti hiperaktif, hipoaktif, tantrum, sakit, kontak mata yang minim, kesulitan bicara dan ketidakpatuhan serta terapis yang tidak bisa mengendalikan emosi. Sedangakan faktor eksternal yang menghambat yakni keinginan orang tua.

\section{Saran}

Peneliti menyarankan bagi Pusat Layanan Disabilitas dan Pendidikan Inklusi agar mengadakan pelatihan bagi terapis tentang pentingnya religiusitas dalam diri terapis yang dapat memberikan kelancaran pada pelaksanaan terapi dan seminar atau penyuluhan tentang penanganan anak seperti pola asuh, pelaksanaan home program dan penerapan diet agar orang tua dapat mengaplikasikan ilmu yang didapatkan. Sehingga akan mendukung kemajuan perkembangan anak dan kekurangan anak dapat dipenuhi secara optimal.

Bagi subjek penelitian, terapis dalam bekerja dapat selalu menerapkan faktor-faktor pendukung jalannya proses terapi, seperti yang telah didapatkan dari hasil penelitian ini agar menghasilkan proses terapi dan perkembangan anak yang baik. Selain itu, menghindari faktor- 
faktor yang dapat menghambat proses dan keberhasilan terapi, yakni dengan memperbanyak wawasan dan pengetahuan tentang emosi serta pengelolaannya dalam menerapi anak.

Bagi orang tua anak dengan autisme agar dapat meningkatkan konsistensi dalam mengerjakan home program dan penerapan diet karena pengaruh dukungan orang tua sangat mendukung proses dan hasil terapi anak, menambahkan pengetahuan dengan mengikuti seminar atau penyuluhan mengenai pola asuh yang benar bagi anak dengan autism, Ikut serta dalam asosiasi atau perkumpulan orang tua yang memiliki anak dengan autisme agar dapat bertukar pengalaman dalam menangani anak.

Bagi peneliti selanjutnya, menelaah lebih lanjut terkait peran religiusitas dalam proses terapi atau menggali efektivitas ritual-ritual keagamaan terhadap pelaksanaan terapi.

\section{Referensi}

Ahmad, Athoullah. “Makna Basmalah dam Perspektif Ilmu Hikmat,” Alqalam, Vol. 24, NO. 3 (Desember 2007).

Anah, Mega Nurul. "Pengaruh Terapi Murottal terhadap Kemampuan Komunikasi Anak Autis di Sekolah Luar Biasa Negeri (SLBN) 1 Bantul Yogyakarta." Fakuktas Kedokteran dan Ilmu Kesehatan Universitas Muhammadiyah Yogyakarta, 2016.

Artanti, Prianca Yulia. "Studi Deskriptif Terapi terhadap Penderita Autisme pada Anak Usia Dini di Mutia Center Kecamatan Bojong Kabupaten Purbaalingga," Indonesian of Joournal of Early Childhood Education Studies, Vol. 01. No. 01 (2012).

Basrowi, dan Suwandi. Memahami Penelitian Kualitatif. Rineka Cipta, 2008.

Fadhli, Aulia. Buku Pintar Kesehatan Anak. Yogyakarta: Pustaka Anggrek, 2010.

Hatta, Kusmawati. "Peran Orangtuadalam Proses Pemulihan Trauma Anak," Gender Equality: Internasionall Journal of Child and Gender studies, Vol. 1, No. 2 (September 2015).

Herdiansyah, Haris. Metode Penelitian Kualitatif untuk Ilmu-ilmu Sosial. Jakarta: Salemba Humanika, 2010.

Heriyono. "Sistem Pelayanan Sosial terhaadap Anak Berkebutuhan Khusus di Yayasan Cahaya Bintang Kecil Punge Blang Cut Banda Aceh." Skripsi, Fakultas Dakwah dan Komunikasi Universitas Islam Negeri Ar-Raniry Darussalam Banda Aceh, 2017.

Jannah, Ananda Nurul, Azizah Husin, dan Imron A Hakim. "Motivasi Terapis dalam Meningkatkan Perkemmbangan Anak Autisme di Bina Autis Mandiri Palembang," Jurnal of Nonformal Education and Community Empowerment, Vol. 2, No. 1 (Juni 2018).

Kharisman, Abu Utsman. Sukses Dunia Akhirat dengan Istighfar dan Taubat. Pustaka Hudaya, t.t.

Kusdianti, Sulisworo, dan Irfan Fahmi. Observasi Psikologi. Bandung: PT. Remaja Rosdakarya, 2015. 
Kuswandi, Yudi. “Doa dalam Tradisi Agama-Agama," Hanifiya: Jurnal Studi Agam-Agama, Vol. 1, No. 1 (2018)

Ma'ruf, Ahmad, dan Lailatul Maghfiroh. "Penggunaan Metode ABA (Applied Behavior Analysis) untuk Meningkatkan Pemahaman Anak Autis pada Pembelajaran Pendidikan Agama Islam di SLB Negeri Pandaan," Al-Murabbi: Jurnal Pendidikan Agama Islam, Vol. 2, No. 2 (Juni 2017).

Martiyani. "Pelaksanaan Terapi Snoezelen pada Anak Autis di YPAC Nasional Sekolah Luar biasa (SLB) Autisme Mitra Ananda Colomadu." Skripsi, Fakultas Ushuluddin dan Dakwah Institut Agama Islam Negeri Surakarta, 2017.

Maulana, Mirza. Anak Autis: Mendidik Anak Autis dan Gangguan Mental Lain Menuju Anak Cerdas dan Sehat. Jogjakarta: KATAHATI, 2014.

Mujiyanti, Dwi Murni. “Tingkat pengetahuan Ibu dan Pola Konsumsi Pada Anak Autis di Kota Bogor." Departemen Gizi Masyarakat Ekologi Manusia Institut Pertanian Bogor, 2011.

Pieter, Herri Zan, Bethsaida Janiwarti, dan N. S Marti Saragih. Pengantar Psikopatologi untuk Keperawatan. Jakarta: Kencana, 2011.

Pradana, Yanuar Dian. "Peningkatan Motorik Kasar Melalui Senam Irama pada Anak Autis Hipoaktif." Fakultas Ilmu Pendidkan Universitas Negeri Surabaya, Jurnal Pendidikan berkebutuhan Khusus, t.t., 2013.

Prasetyoningsih, Luluk Sri Agus. "Tindak Bahasa Terapis dalam Intervensi Klinis pada Anak Autis," Litera, Vol. 13, No. 2 (Oktober 2018).

Pratiwi, Rifmie Arfiriana, dan Fillah Fithra Dieny. "Hubungan Skor Frekuensi Diet Bebas Gluten Bebas Casein dengan Skor Perlaku Autis," Jurnal of Nutrition College, Vol. 3, No, 1 (2014).

Rachmayana, Dadan. Diantara Pendidikan Luar Biasa, Menuju Anak Masa Depan yang Inklusif. Jakarta: Luxima Metro Media, 2013.

Rahmadi. Pengantar Metodelogi Penelitian. Banjarmasin: Antasari Perss, 2011.

Rahmasari, Lisda. "Pengaruh Kecerdasan Intelektual, Kecerdasan Emosi dan Kecerdasan Spiritual terhadap Kinerja Karyawan," Majalah Ilmiah INFORMATIKA, Vol. 3, No. 1 (Januari 2012).

Rahmatullah, Azam Syukur. "Konsepsi Pendidikan Kasih Sayang dan Konstribusinya terhadap Bangunan Psikologi Pendidikan Islam," LITERASI, Vol. 6, No. 1 (Juni 2014).

Sujarweni, V Wiratna. Metodologi Penelitian. Yogyakarta: Pustaka Baru Press, 2014.

Sulistyawati, Evy. "Penerapan Metode Terapi Perilaku pada Anak Usia Dini dengan Autisme (Studi Deskriptif di Pusat Pelayanan Disabilitas dan Pendidikan Inklusi Kota Surakarta dan Mutiara Center Kota Surakarta)." Skripsi, Fakultas Ilmu Pendidikan Universitas Negeri Semarang, 2018.

Tamba, Alvin. "Tren Penderita Autisme Meningkat," 2 April 2018. http://m.harnas.co/2018/04/01/tren-penderita-autisme-meningkat.

Turruqoyyah, Izza. "Pelaksanaan Terapi Musik untuk Anak Berkebutuhan Khusus (ABK) di Yayasan Pembinaan Anak Cacat (YPAC) Surakarta." Skripsi, Fakultas Ushuluddin dan Dakwah Institut Agama Islam Negeri Surakarta, 2017.

Ubaedy, AN. Quantum Sabar. Jakarta: KinzBooks, 2009 
Waid, Abdul. Dahsyatkan Potensi Otakmu dengaan Shalat. Jogjakarta: DIVA Press (Anggota IKAPI), 2012.

Winarno, F. G. Autisme dan Peran Pangan. Jakarta: PT. Gramedia Pustaka Utama, 2013.

Yasmin, Puti Aini. "Pentingnya Terapi Sejak Dini pada Anak Berkebutuhan Khusus," 18 Maret 2017. https://health.detik.com/anak-dan-remaja/d-3450544/pentingnya-terapi-sejak-dinipada-anak-berkebutuhan-khusus.

Zahara, Fenty. "Pengendalian Emosi ditinjau dari Pola Asuh Orang Tua pada Siswa Usia Remaja di SMA Utama Medan," Kognisi Jurnal, Vol. 1, No. 2 (Februari 2017).

\begin{tabular}{|l|l|l|l|l|}
\hline Submit & Review & Revisi & Diterima & Publis \\
\hline $02-03-2020$ & - & - & $18-03-2021$ & $25-3-2021$ \\
\hline
\end{tabular}

Elvina Rizky, Irfan Noor, dan Mahdia Fadhila

Progran Studi Psikologi Islam

Fakultas Ushuluddin dan Humaniora

Universitas Islam Negeri Antasari Banjarmasin

Email : elvinarizkyreal@gmail.com 